\title{
Self-compacting mortar with sugarcane bagasse ash: development of a sustainable alternative for Brazilian civil construction
}

\author{
Rafael Germano Dal Molin Filho ${ }^{1}$ (D) Daniel Angelo Longhi ${ }^{1}$ • \\ Rodrigo Clemente Thom de Souza ${ }^{1} \cdot$ Mateus Meneghetti Ferrer $^{2}$. \\ Romel Dias Vanderlei ${ }^{3}$ Paulo Roberto Paraíso ${ }^{3}$. Luiz Mário de Matos Jorge Pa $^{3}$
}

Received: 9 December 2017 / Accepted: 5 March 2018

(C) Springer Science+Business Media B.V., part of Springer Nature 2018

\begin{abstract}
The technically controlled use of industrial residues in replacement of natural resources for the production of new products with comparable quality presents a great economic and sustainable contribution. In this sense, this work sought to develop selfcompacting mortars with partial replacement of sand by sugarcane bagasse ash (SCBA) by a rheological study of the optimum dosage of superplasticizer to cement ratio. The selfcompacting parameters were obtained by analyzing the relative flow area and relative flow time, adapting from mortar flow tests. Besides one sample composed only of sand as fine aggregate, the self-compacting mortars presented replacement rates of sand by sugarcane bagasse ash, in mass of 5,10,20, 25, 30 and $40 \%$. The results demonstrated that it was
\end{abstract}

Rafael Germano Dal Molin Filho

rafaelfilho@ufpr.br

Daniel Angelo Longhi

ealdaniel@ufpr.br

Rodrigo Clemente Thom de Souza

thom@ufpr.br

Mateus Meneghetti Ferrer

mmferrer@yahoo.com.br

Romel Dias Vanderlei

rdvanderlei@uem.br

Paulo Roberto Paraíso

prparaiso@uem.br

Luiz Mário de Matos Jorge

lmmjorge@uem.br

1 Federal University of Paraná, Rua João Maximiano, 426, Vila Operária, Jandaia do Sul, Paraná CEP 86.900-000, Brazil

2 Modeling and Molecular Simulations Group, São Paulo State University, UNESP, Bauru, São Paulo 17.033-360, Brazil

3 State University of Maringá, Avenida Colombo, 5.790, D - 90, Maringá, Paraná CEP 87.020-900, Brazil 
possible to reduce up to 489 and $56 \mathrm{~kg}$ of sand and cement, respectively, to produce $1 \mathrm{~m}^{3}$ of self-compacting mortar with sugarcane bagasse ash considering the expressive replacement rate of $40 \%$ of sand by SCBA.

Keywords Self-compacting concrete $\cdot$ Reuse $\cdot$ Rheology $\cdot$ Agro-industrial residues · Sustainability

\section{Introduction}

Concern for the sustainability of ecosystems is a constant dilemma for modern civilizations. The unbridled extraction of natural resources, triggered during the industrial revolution and intensified with the industrial actions of twentieth and twenty-first centuries, is one of the significant causes of the environmental instability. The residues generated need to be minimized and require more appropriate treatment, reuse and recycling (Nogueira et al. 2012; Moisés et al. 2013).

The self-compacting mortar (SCM) offers several benefits associated with the product and the operational processes, both in precast plant operations and in direct applications at construction sites. The developments of by-products associated with self-compacting concrete (SCC), such as the paste and SCM, are also fundamental for the determination of the self-compacting properties of the self-leveling concretes (Safi et al. 2013; Chatterjee and Das 2013). In this context, there are a lot of studies that have developed SCM with the most varied materials (nanoparticles, industrial residues as the aluminum, among others) to improve the characteristics of resistance, workability and consumption, proposing at the same time, the use of new components in a technical and controlled way (Rao et al. 2015; Silva and Brito 2015; Mohseni et al. 2015; Madandoust et al. 2015).

The big challenges of these developments, whether for the paste, the mortar or even the concrete, are linked to the rheological aspects related to the establishment of fluidity, cohesion and segregation resistance. It is important to emphasize that each of these byproducts requires specialized investigations with appropriate tests and techniques (ABNT NBR 15823-1 2017; Gomes and Barros 2009; EFNARC 2005; Okamura and Ouchi 2003).

Various dosage methods of SCC use the development of SCM as basis to guarantee the self-compatibility in the fresh state and the required mechanical resistances in the final state (Gomes 2002). The Okamura and Ouchi (2003) method seeks to establish parameters for the study of these properties: the relative flow area $\left(\Gamma_{\mathrm{m}}\right)$, assumed as $G_{\mathrm{m}}$ in this research, and the relative flow time $\left(R_{\mathrm{m}}\right)$, which measures the deformability by mortar flow test and the viscosity by mortar funnel test, respectively. Based on the method of Nepomuceno et al. (2012), Silva and Brito (2015) attested the importance of SCM for the optimized development of SCC, both for results in fresh and hardened state.

The sugarcane bagasse ash (SCBA), which is the industrial residue used in this research as a fine aggregate, as well as the sand, is classified by the ABNT NBR 10004 (2004) as rural residue belonging to class II and not inert. The SCBA comes from the process of energy cogeneration in boilers by burning the sugarcane bagasse. Based on data from CONAB (2017) and FIESP/CIESP (2012), for the 2017/2018 harvest, up to 240,000 ton of SCBA can be produced just in the state of Paraná (Brazil), if all the bagasse generated by the production of sugarcane is reused in processes of energy cogeneration. The potential of SCBA generation is much more significant when these same indicators allow estimating 
that the expected 646.34 million tons of sugarcane, in the 2017/2018 Brazilian harvest, would present the potential for production of up to 4008,000 tons of SCBA.

The SCBA generated in processes of energy reutilization, from the bagasse burning in the boilers and furnaces, present heterogeneous characteristics in the physical aspects (related to form, size and coloration), as well as in the variability of the chemical composition. These characteristics are related to the variations of the internal burning conditions, generated by the temperature profile in the boiler extension. In addition, other aspects of the generation process act in the unadjusted formation (e.g., the internal combustion atmosphere, the gas treatment and washing system, the subsequent treatment process and the ashes storage) for both light ashes, from gases and particulates in suspension, and heavy ashes, which are burnt from the bottom of the boiler. Furthermore, the inherent variations in the characteristics that precede the burning process such as harvesting technology (manual or mechanical), the way of extraction of the broth in the initial process that results in the generation of the bagasse with the possibility of encompassing other parts of sugarcane, the moisture of the bagasse, which is usually deposited in uncovered areas, and the variety of sugarcane and the soil where it was cultivated must be considered. The considerations of such factors in SCBA generation motivated several researchers to develop the application of SCBA in the civil construction as substitute of fine aggregates for structural filling. Sales and Lima (2010) partially replaced sand by SCBA obtaining better mechanical results than concrete reference samples. Modani and Vyawahare (2013), Vanderlei et al. (2014) and Moretti et al. (2016) presented results on the use of SCBA in the substitution and composition with sand to produce mortars and concretes. Faria et al. (2012) and Zhang (2013) developed compositions in which SCBA was used as an aggregate in the blending of materials to produce bricks.

Some researchers have developed additional controls of reburning, processing and grinding at laboratory scales for SCBA generation with chemical and physical characteristics suitable to pozzolanic investigations, such as Crespi et al. (2011) and Bahurudeen and Santhanam (2015).

In general, the current manuscript aimed to develop self-supported mortars with substitution rates of sand by SCBA. The rheological analysis of $G_{\mathrm{m}}$ and $R_{\mathrm{m}}$ parameters was carried out to classify the characteristics of the final material. Finally, investigations were elaborated by means of RSM package of R software (R Development Core Team 2016) to estimate the parameters of mathematical models of second-order response surface.

\section{Materials and methods}

The physical characterization of materials, specially granulometric profiles of sand and SCBA, were performed according to ABNT NBR 7181 (2016) and ABNT NBR 7211 (2009a, b). The SCBA was collected from Iguatemi Sugarcane Plant (Maringá, Brazil) of Usaçúcar Group. The chemical composition of SCBA was determined by X-ray fluorescence (XRF), and the patters of SCBA were verified by X-ray diffraction (XRD). The analytical LOI values of the sample were determined by comparing the weight before and after ignition for $240 \mathrm{~min}$ at $600{ }^{\circ} \mathrm{C}$.

The development of SCMs was based on the composition of the self-compacting paste prepared by Molin Filho et al. (2011), which did not contain the SCBA. The self-compacting parameters of the mortar were investigated by technical adaptations of the mini-conical slump 
flow test, performed with the mini-cone for mortars, which was based on the techniques used by Okamura and Ouchi (1999) and (2003).

SCMs were composed of cement (CP II E 32), calcitic limestone filler, third-generation superplasticizer chemical additive (Glenium 51-Manufacturer Basf), quartzose sand, crystalline SCBA (burning above $700{ }^{\circ} \mathrm{C}$ ) and water in compliance with ABNT NBR 15900-1 (2009a, b).

The preparation, production and tests with the mortars were carried out with a mortar mixer of $5 \mathrm{~L}$ in a speed of $60 \pm 5 \mathrm{rpm}$, a glass plate with a mini-cone (Fig. 1a), a thermometer, a chronometer, a precision scale of $2000 \mathrm{~g} \pm 0.01$ and a bench level.

The preparation, mixture and pouring stages were performed as described by Molin Filho et al. (2011) with the addition of sand and SCBA in the initial of the preparation. It is highlighted that during the experiments, the temperature of the mortars maintained around $21 \pm 3{ }^{\circ} \mathrm{C}$ with relative air humidity between 45 and $60 \%$.

The used mini-cone had a bottom diameter $\left(d_{0}\right)$ of $125 \mathrm{~mm}$ and height of $63 \mathrm{~mm}$. In the method, the final flow area $(d)$ was calculated with the average of two perpendicular measurements and was used to obtain the $G_{\mathrm{m}}$ according to Eq. (1).

$$
G_{m}=\left(\frac{d}{d_{0}}\right)^{2}-1.0
$$

(a)

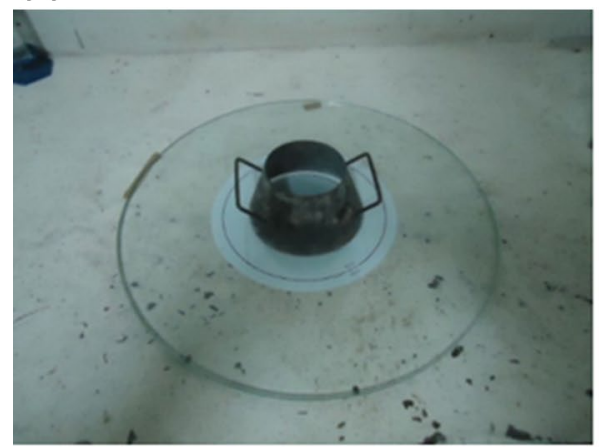

(c)

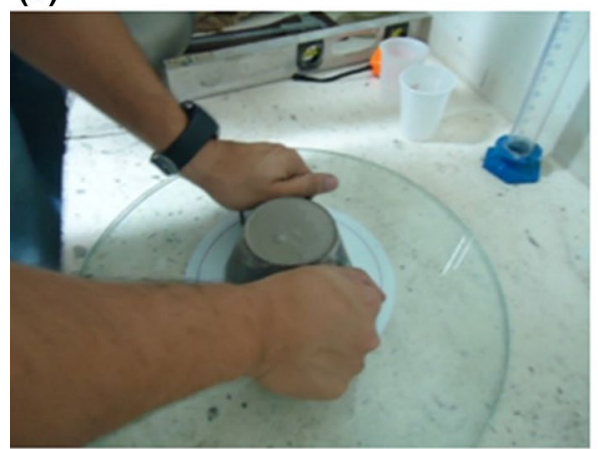

(b)

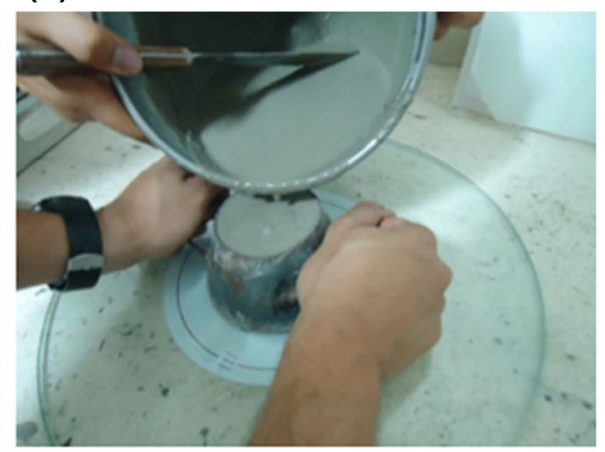

(d)

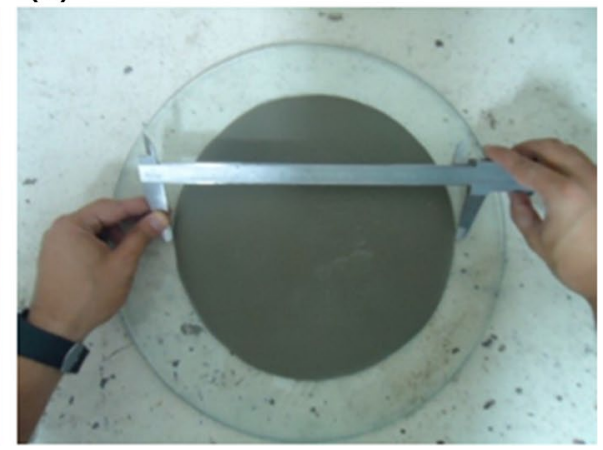

Fig. 1 Images of the apparatus and the test of mini-cone for mortars. a Mini-cone and the glass plate of $400 \mathrm{~mm}$ diameter; b mortar pouring; c leveled mortar inside the mini-cone; $\mathbf{d}$ appearance of the mortar after stabilization of the movement and measurement of the flow area diameter 
$G_{\mathrm{m}}=$ Relative flow area, expected value of $5 \pm 0.5, d_{0}=$ initial diameter of the mixture $(\mathrm{mm}), d=$ average of two perpendicular measurements of the flow area $(\mathrm{mm})$.

Similarly, it was performed an adaptation of Okamura and Ouchi (2003) method to calculate the $R_{\mathrm{m}}$. In these adaptations, as shown in Eq. (2), instead of using the V-Funnel for mortars, the flow time $(t)$ was obtained by the measurement of the time between the time zero of the flow and the final stabilization of the volume of the mini-cone in the plate. Therefore, an experimental proposal was assumed to obtain SCMs. It is important to emphasize that the obtained SCMs will be used as basis to develop compositions of SCC, which require more elaborated and normalized experiments to measure parameters as the viscosity and the fluidity.

$$
R_{m}=\frac{10}{t}
$$

$R_{\mathrm{m}}=$ Relative flow time, expected value of $1 \pm 0.1, t=$ mortar flow time (s).

For these tests, Edamatsu et al. (1999) suggested a final diameter of the flow area of 200-283 $\mathrm{mm}\left(3 \leq G_{\mathrm{m}} \geq 7\right)$ and flow time of 5-10 s $\left(1 \leq R_{\mathrm{m}} \geq 2\right)$. According to Takada and Walraven (2001), to produce SCC, the $G_{\mathrm{m}}$ and $R_{\mathrm{m}}$ values need to be of 5.0 and 1.0 , respectively. These are referential numbers to obtain the content of superplasticizer in the paste and the consequent determination of water/filler (w/f) and water/cement $(w / c)$ ratios. Nunes (2001) reported that within the allowable ranges, higher values of $G_{\mathrm{m}}$ provide mortars with higher deformability, while lower values of $R_{\mathrm{m}}$ are characteristic of mortars with high viscosities. As mentioned in Eqs. (1) and (2), the criteria for verifying the optimum dosage condition of superplasticizer in the mortars considered $G_{\mathrm{m}}=5 \pm 0.5$ and $R_{\mathrm{m}}=1 \pm 0.1$. Based on Edamatsu et al. (1999), as a further reference, it was estimated that the optimum SCMs would reproduce flow areas with an average diameter " $d$ " within the range of $300 \pm 30 \mathrm{~mm}$, by the volume of the used mini-cone in comparison with the mini-cone of Okamura and Ouchi (2003).

The experimental challenge to obtain these SCMs was to incorporate the sand (sand/ cement $[s / c]$ ratio of 2 ), in the same way as shown by Gomes (2002), with the projected replacements of sand by SCBA, to the trace of Molin Filho et al. (2011) paste (f/c ratio of 0.4 and $w / c$ ratio of 0.5 ). Therefore, at first, SCM to be tested assumed the paste dosage of Molin Filho et al. (2011) only with the sand as fine aggregate. Subsequently, the replacement ranges of 5,10, 20, 25, 30 and $40 \%$ of sand by SCBA were assumed for the analyses. For each composition, the $G_{\mathrm{m}}$ and $R_{\mathrm{m}}$ parameters were evaluated. To obtain the optimum value for each replacement range, simulations with $\mathrm{sp} / c$ values around the optimum relation of the previous replacement range were performed, by means of a progressive and constructivist experimental method. The cement consumption for the mortar volume of $1 \mathrm{~m}^{3}$ was obtained by Eq. (3). The specific mass was calculated by the measurement of the mortar mass in a cubic container of $0.001 \mathrm{~m}^{3}$ previously calibrated.

$$
M_{c}=\frac{\rho_{\mathrm{scm}} \times V_{\mathrm{scm}}}{1+w / c+f / c+\mathrm{sp} / c+s / c+\mathrm{SCBA} / c}
$$

$M_{\mathrm{c}}=$ mass of cement in $\mathrm{kg}$ per $1 \mathrm{~m}^{3}, \rho_{\mathrm{scm}}=\mathrm{SCM}$ specific mass in $\mathrm{kg} / \mathrm{m}^{3}, V_{\mathrm{scm}}=\mathrm{SCM}$ volume in $\mathrm{m}^{3}, w / c=$ water/cement ratio, $f / c=$ filler/cement ratio, $\mathrm{sp} / c=$ superplasticizer/cement ratio, $s / c=$ sand/cement ratio, $\mathrm{SCBA} / c=\mathrm{SCBA} /$ cement ratio.

After calculating the mass of cement, it was possible to obtain the consumption of all the other materials for $1 \mathrm{~m}^{3}$ of mortar by applying the final factors obtained in relation to the cement. The optimum compositions of $G_{\mathrm{m}}$ and $R_{\mathrm{m}}$ were mathematically modeled 
in second-order configurations by means of the response surface methodology (RSM) of $\mathrm{R}$ software (R Development Core Team 2016). The response surface and contour graphs were plotted to evaluate the predictions of the models versus the experimental values.

\section{Results and discussion}

\subsection{Physical and chemical characterization of SCBA}

The sand had specific mass of $2642.5 \mathrm{~kg} / \mathrm{m}^{3}$, maximum diameter of $0.6 \mathrm{~mm}$ and fineness modulus of 1.7. The used SCBA, from Iguatemi Sugarcane Plant (Maringá, Brazil) of Usaçúcar Group, was from the same sample of Moisés et al. (2013) studies. It had a specific mass of $2640 \mathrm{~kg} / \mathrm{m}^{3}$ and the highest proportion of its particles, around $73 \%$, had a size between 150 and 250 micrometers. It is important to emphasize that the SCBA was used in the natural condition, being only sieved in the mesh $0.595 \mathrm{~mm}$ (\#30), to remove the organic impurities (Fig. 2).

Figure 3 shows sand and SCBA granulometric profiles characterized by ABNT NBR 7181 (2016) and ABNT NBR 7211 (2009a, b).

The percentage of particles with a maximum dimension of $1.2 \mathrm{~mm}$ is similar between the two materials, as shown in Fig. 3. However, the proportions are very divergent for particles with dimensions smaller than $0.42 \mathrm{~mm}$. While about $99.4 \%$ of the SCBA particles are less than $0.42 \mathrm{~mm}$, only $33.5 \%$ of the sand particles are $<0.42 \mathrm{~mm}$. This difference is even more significant for particles that are smaller than $0.25 \mathrm{~mm}$, in which about $80 \%$ of the SCBA particles and $0.3 \%$ of the sand particles are in this size range. Moreover, only $3.6 \%$ of SCBA particles are less than $0.075 \mathrm{~mm}$. This information corroborates with the indication for the use of SCBA in substitution of the sand in its raw state (without grinding). According to ABNT NBR 5752 (2014), for a material be evaluated as pozzolanic material in substitution to the Portland cement, at least $80 \%$ of its particles need to be smaller than $0.045 \mathrm{~mm}$.

Fig. 2 Visual aspect of a sample of sugarcane bagasse ash (SCBA)

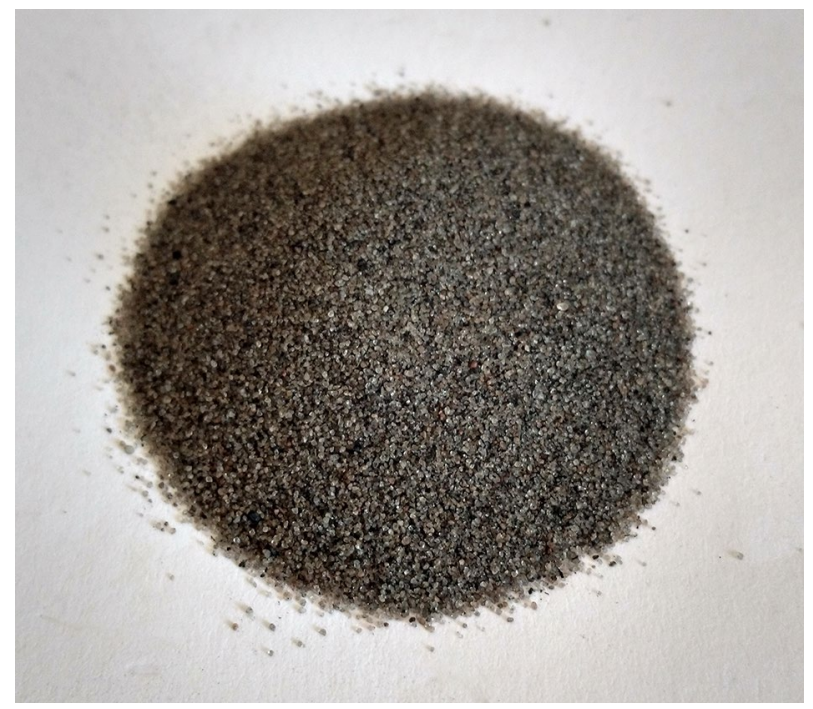




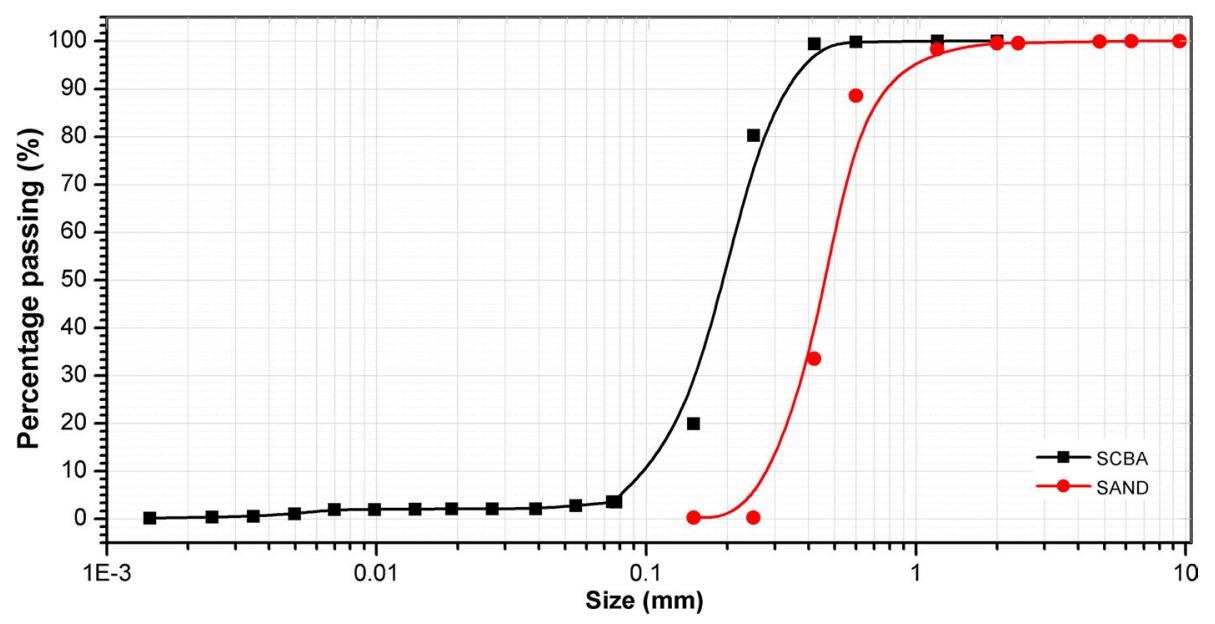

Fig. 3 Sand and SCBA granulometric profiles

Table 1 shows the SCBA composition studied by X-ray fluorescence (XRF).

In Table 1 , it is possible to observe the predominant presence of silicon dioxide $\left(\mathrm{SiO}_{2}\right)$, in accordance with results of Moisés et al. (2013). Figure 4 presents the X-ray diffraction (XRD) pattern of the SCBA. The results indicated that the sample is crystalline with an $\alpha$-quartz structure (standard pattern number 201354-ICSD database) (Lager et al. 1982). The loss on ignition (LOI) was $0.9 \%$.

The physical and chemical characteristics of the crude residue investigated in this research have provided the indication for an application of SCBA as an aggregate for structural filling. To do that, only the separation of particles by sieving (incomplete burning fibers and organic material) was needed. The prospect of promoting an application that requires the incorporation of the residue into new products with the lowest energy after its conventional process of generation was achieved. This has led to concerns about the development of a responsible social and environmental destination for SCBA and to a low cost of preparation. The combination of these aspects is fundamental in the generation of added value regarding the destination of SCBA and consequently fomentation of the interest of the sugarcane plants in the accomplishment of this solution.

Table $1 \mathrm{X}$-ray fluorescence (XRF) results of SCBA composition

\begin{tabular}{lc}
\hline Elements & Mass (\%) \\
\hline $\mathrm{SiO}_{2}$ & 97.9 \\
$\mathrm{Al}_{2} \mathrm{O}_{3}$ & 0.3 \\
$\mathrm{~K}_{2} \mathrm{O}$ & 0.1 \\
$\mathrm{CaO}$ & 0.1 \\
$\mathrm{Fe}_{2} \mathrm{O}_{3}$ & 1.2 \\
$\mathrm{TiO}_{2}$ & 0.3 \\
Other elements & 0.1 \\
\hline
\end{tabular}




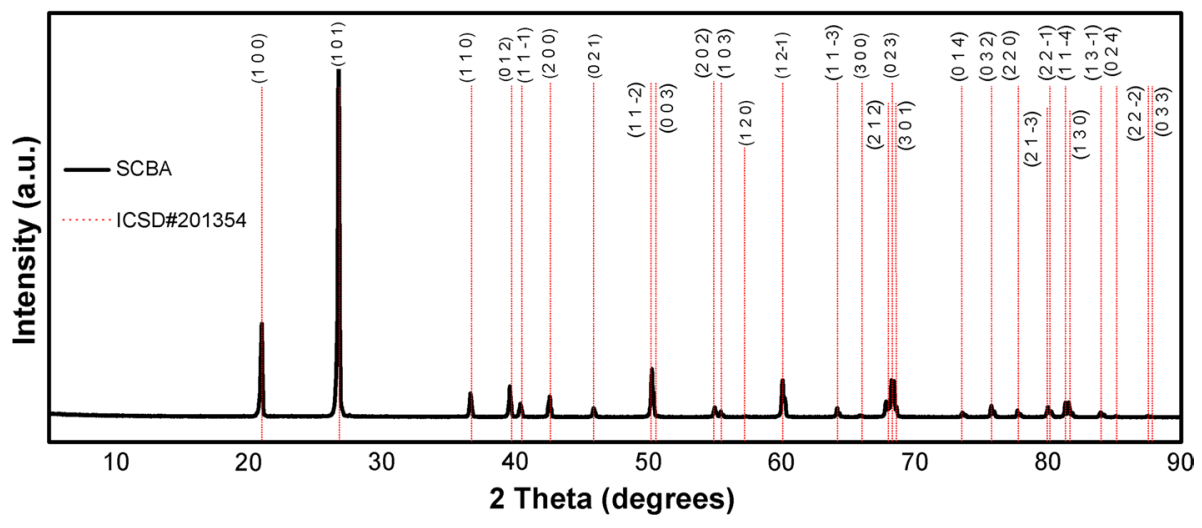

Fig. 4 X-ray diffraction (DRX) spectrum of SCBA

\subsection{Development of the self-compacting mortars compositions}

Table 2 presents the composition and the $G_{\mathrm{m}}$ and $R_{\mathrm{m}}$ values of all the studied samples to carry out the analysis of the optimum dosage of $\mathrm{sp} / \mathrm{c}$ for all the replacements of sand by SCBA. In total, 26 samples of mortars numbered from 0 to 25 were evaluated in this stage.

The mortar " 0 " was initially developed as a reference for all the subsequent samples. This mortar had the same unitary composition of Molin Filho et al. (2011) paste with the difference of the addition of the $s / c$ ratio $=2$ ( $100 \%$ of sand). It presented satisfactory results, because with the same dosage of $\mathrm{sp} / c=0.004$ of the paste, it was possible to obtain the expected $G_{\mathrm{m}}$ and $R_{\mathrm{m}}$ values based on the requirements taken into consideration in this research for SCM. Therefore, these results showed that this sample could serve as a fundamental reference for SCMs, although still without SCBA.

It is also worth noting that the rows marked in bold in Table 2 represent the best combinations of materials by the $G_{\mathrm{m}}$ and $R_{\mathrm{m}}$ tests in each rate of SCBA/s. It is also possible to observe that the complementary criterion that estimated the average diameter " $d$ " of the flow area was met, where all of them were within the allowable values of this method. In this stage, mortars with SCBA were developed with potential for production of SCC. It was noted that the increasing presence of SCBA in the mixture would require additions of superplasticizer to be preserved the expected characteristics of fluidity, homogeneity and cohesion. The ranges of replacement of sand by SCBA from 5 to $20 \%$ showed that, up to this variation, it is possible to maintain a consumption of sp/c very close to the consumption of the mortar that contain $100 \%$ of sand, i.e., sp/c of $0.0042(+5 \%)$. The replacements of 25,30 and $40 \%$ demanded an increase in consumption, with respective values of 0.45 , 0.5 and $0.58 \%$ in relation to the mass of the cement. Based on Eq. (3), the material consumptions for each cubic meter of mortar were calculated and are shown in Table 3.

All the material consumption of the optimum mortars, presented in Table 3, are within allowable ranges to produce SCCs because the volume of mortar in these SCCs should be up to $70 \%$ of the mixture and the volume of coarse aggregates should be about $30 \%$ (EFNARC 2005; Gomes 2002). In this condition, the cement consumption for $1 \mathrm{~m}^{3}$ of concrete originated from SCM 0, which requires the higher amount of cement, is around $370 \mathrm{~kg}$, and for SCM 25 is around $331 \mathrm{~kg}$. Consequently, when it considers the fines dosage [cement + filler $+27 \%$ of the mass of the SCBA that is $<0.150 \mathrm{~mm}$ (EFNARC 2005)], 


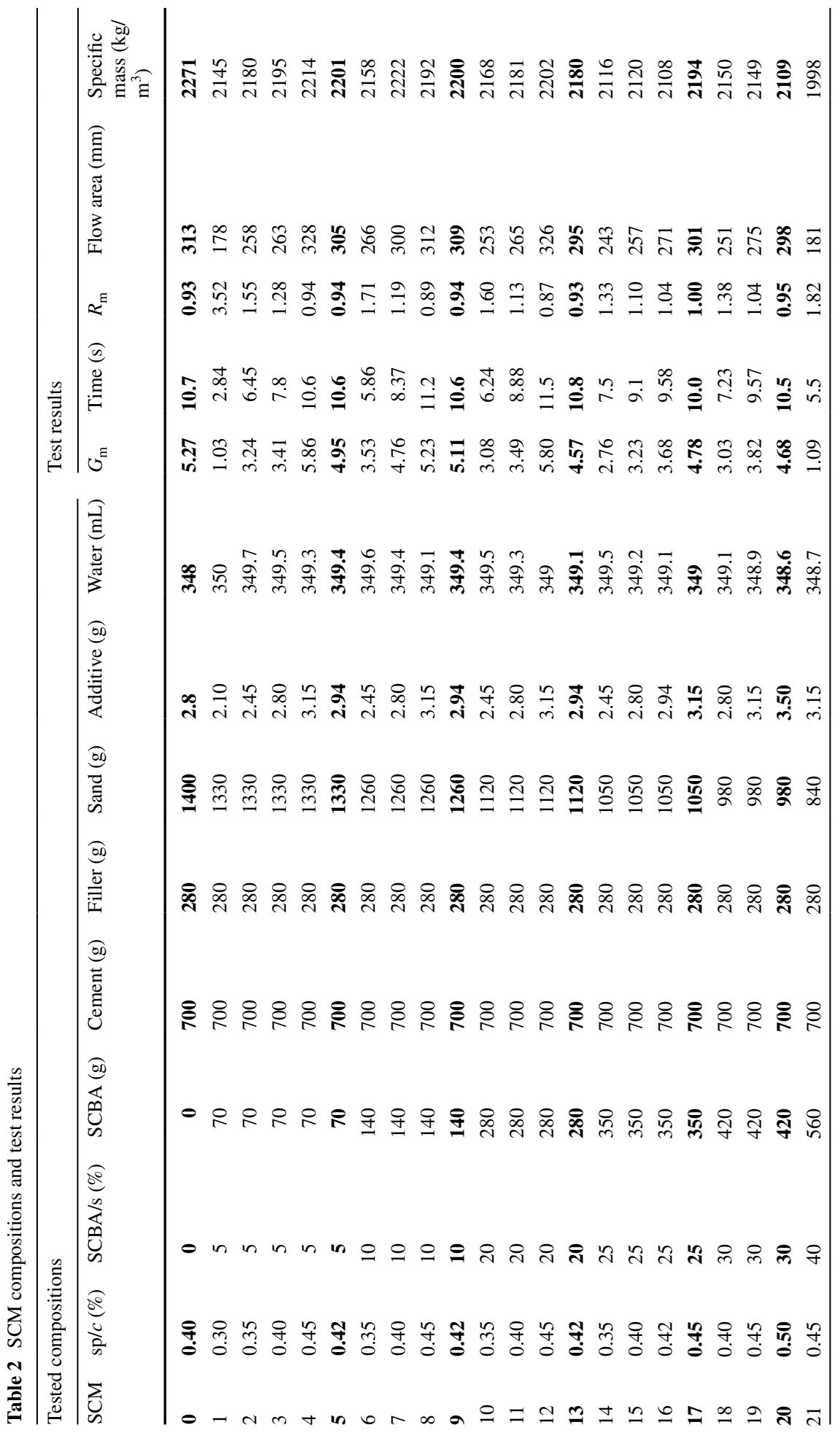




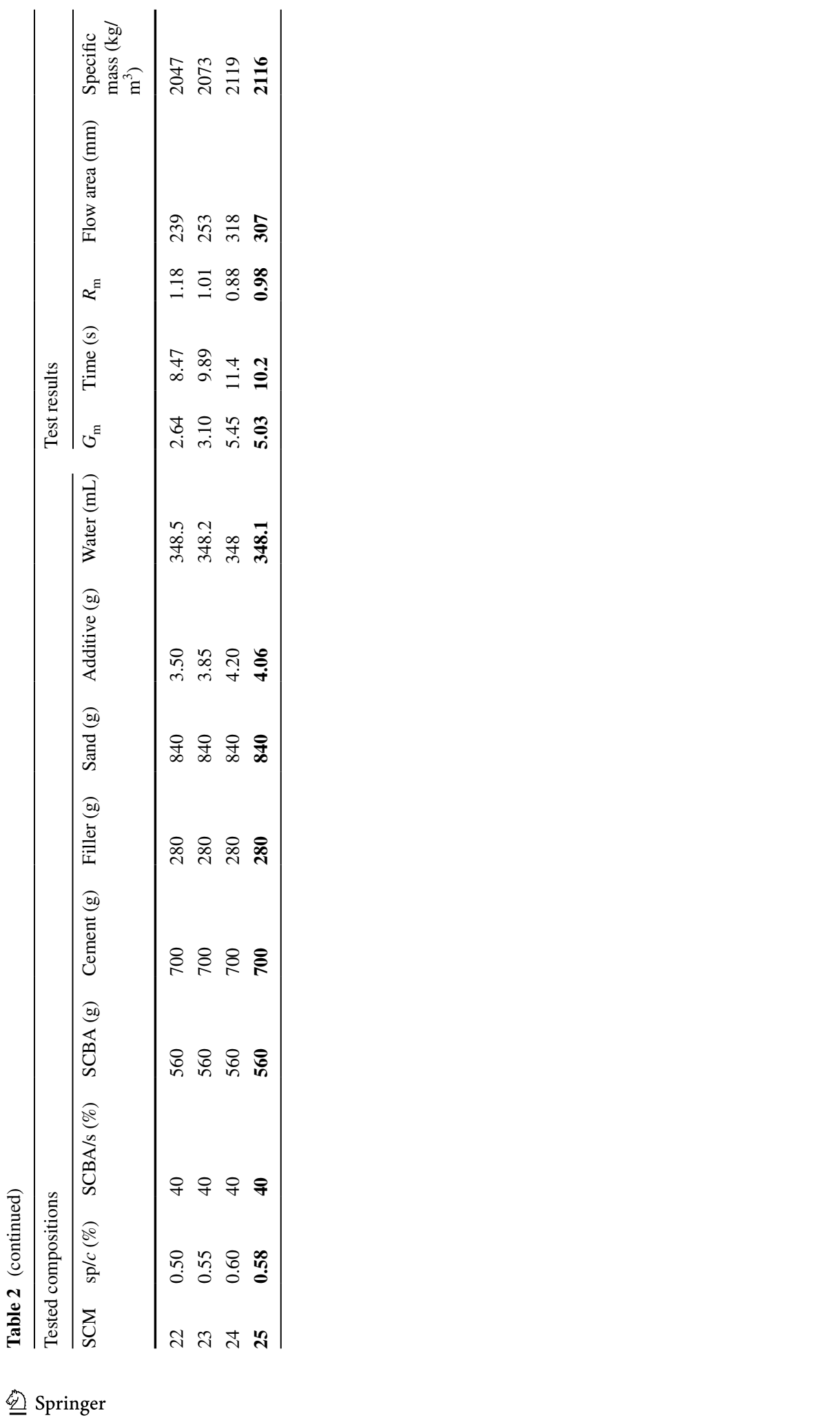


Table 3 Material consumption for $1 \mathrm{~m}^{3}$ of mortar

\begin{tabular}{llllllll}
\hline $\begin{array}{l}\text { Components } \\
\mathrm{kg})\end{array}$ & SCM 0 & SCM 5 & SCM 9 & SCM 13 & SCM 17 & SCM 20 & SCM 25 \\
& SCBA 0\% & SCBA 5\% & SCBA 10\% & SCBA 20\% & SCBA 25\% & SCBA 30\% & SCBA 40\% \\
\hline Cement & 528 & 509 & 509 & 505 & 504 & 479 & 472 \\
Filler & 211 & 204 & 204 & 202 & 202 & 192 & 189 \\
Sand & 1056 & 968 & 917 & 807 & 757 & 671 & 567 \\
SCBA & 0.0 & 51 & 102 & 202 & 252 & 288 & 378 \\
Water & 264.1 & 254.7 & 254.6 & 252.3 & 252.2 & 239.7 & 236.2 \\
Superplasticizer & 2.11 & 2.14 & 2.14 & 2.12 & 2.27 & 2.40 & 2.74 \\
\hline
\end{tabular}

the sum of the values for these two mortars, SCM 0 and SCM 25, would provide for the concrete with $70 \%$ of volume of SCM, the values of 517 and $534 \mathrm{~kg}$ of fines consumption, respectively. These values are within the recommended ranges of EFNARC (2005), from 380 to $600 \mathrm{~kg} / \mathrm{m}^{3}$.

Figure 5 shows the variations in percentage of consumption of dry components in relation to mortar " 0 " considering the consumptions related in Table 3 and the consumptions dimensioned by Eq. (3) as parameters. In the same sense, Fig. 6 shows the variation for the liquid components. Such variations are inherent to the differences in consumption due to the specifications of the dosages in relation to the cement, and by the respective variations of the specific mass obtained experimentally.

All the materials showed projections for the reduction in the consumption with the increment of higher rates of SCBA/sand, as shown in Fig. 5. The cement and filler had reductions in close percentages at all SCBA/sand rates, reaching maximum reduction values of about $11 \%$ for cement and filler at SCM 25, which potentiates the reduction of 56 and $22 \mathrm{~kg}$ of each component per $1 \mathrm{~m}^{3}$, respectively. Although the experimental replacement of SCBA/sand for SCM 25 was performed with $40 \%$ due to the decrease of

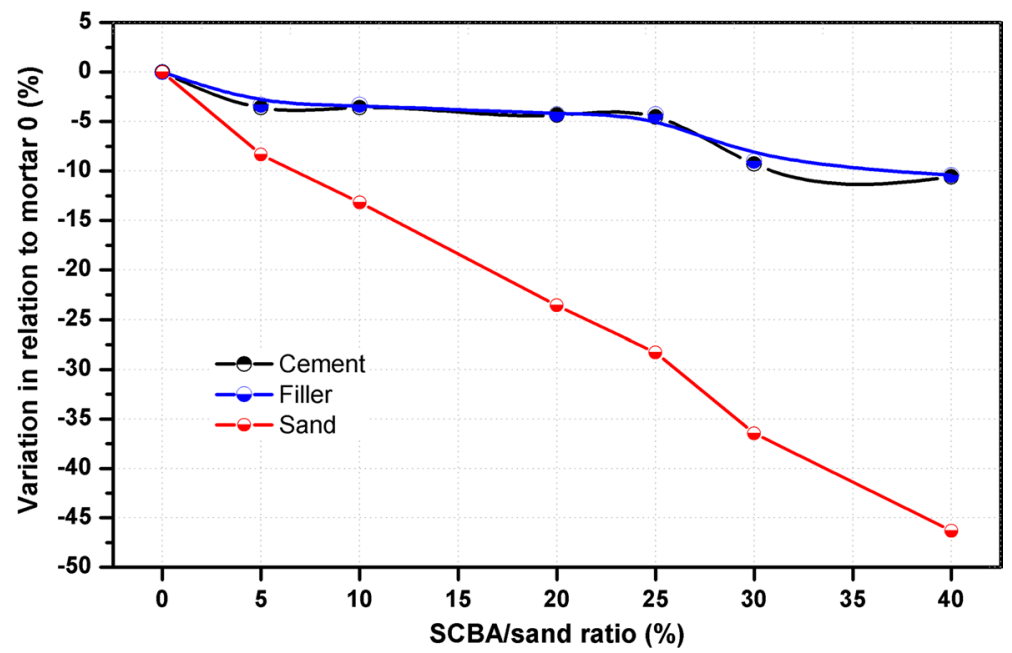

Fig. 5 Variations of the consumption of dry components in relation to the reference mortar 


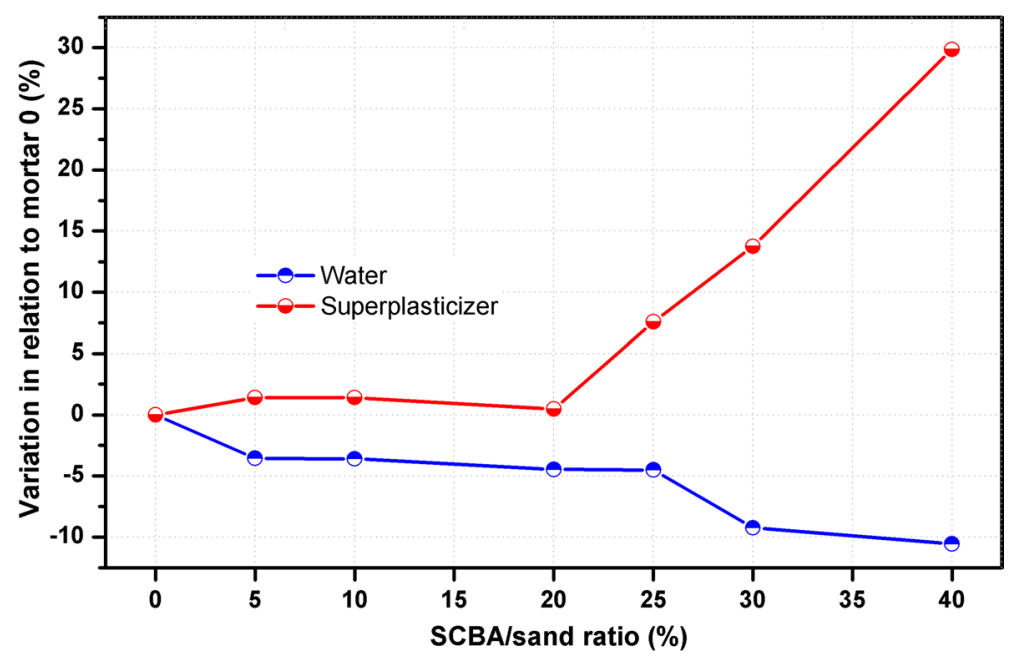

Fig. 6 Variations of the consumption of the liquid components in relation to the reference mortar

$0.155 \mathrm{~kg}$ in the specific mass, the reduction in the consumption of $46 \%$ of sand $(489 \mathrm{~kg})$ in $1 \mathrm{~m}^{3}$ of SCM was possible in direct comparison with the reference SCM " 0 ." In other replacement levels, this considerable reduction of sand was also evidenced, as the decrease of $249 \mathrm{~kg}$ (24\%) for the replacement rate of $20 \%$.

Figure 6 shows a decrease in water consumption, which contrasts with the increase in consumption of superplasticizer. To guarantee the expected workability in SCMs with higher SCBA/sand dosages, it is necessary to increase the $\mathrm{sp} / c$ ratio. However, at the same time, it is possible to reduce the water projection in SCM. This factor contributed directly to the experimental effect of the decrease in the specific mass in relation to SCM "0," for all the mortars developed with contributions for projections of lower component consumption. Besides that, the use of SCBA provided an improvement in the microstructural filling as an additional factor. The packing of the fine aggregates, due to the granulometric differences (see Fig. 2), resulted in more distributed plots for particles smaller than $0.25 \mathrm{~mm}$ and larger than $0.075 \mathrm{~mm}$. This range represents more than $75 \%$ of SCBA particles. Therefore, a percentage of these spaces, previously occupied by fines (filler and cement) and water, began to be occupied by SCBA particulates.

Figures 5 and 6 show that, apart from superplasticizer, it is possible to produce selfcompacting mortar with up to $40 \%$ of sand replacement by SCBA. To maintain the cohesion and fluidity aspects expected in the $G_{\mathrm{m}}$ and $R_{\mathrm{m}}$ tests, it was necessary to assume percentages of $\mathrm{sp} / c$ greater than the reference trace from the SCBA/sand replacement rate of 20 , up to $30 \%$ higher for SCM 25 . However, all other components of natural origin presented reductions in their actual consumption, in which this practice specially makes it possible to assume a responsible and effective technical allocation for SCBA.

Considering the Brazilian potential of SCBA generation, it would be possible to apply SCM 25 in civil construction materials saving more than 4.008 .000 tons of sand to produce up to 8.196.319 cubic meters of SCM. If this volume of SCM was applied in the production of SCC, with the minimum volume of mortar of 63\% (EFNARC 2005), it would be possible to obtain about $13.010 .030 \mathrm{~m}^{3}$ of concrete. This volume of SCC 
would be sufficient to build more than 160 similar stadiums to Maracanã, or even so, a hydroelectric power plant like Itaipu (Santos 2011; Itaipu Binacional 2017).

\subsection{Adjustment of the response surface models}

The parameters of second-order models ( $\mathrm{SO}$ ) were adjusted for the representations of the response surfaces by means of RSM package of R software ( $\mathrm{R}$ Development Core Team 2016). Table 2 is used as basis to obtain Table 4 with the coded data of the model, by a representation based on the analysis of a central composite design (CCD), fixed in the central range of $20 \%$ (SCM 13). Due to the software inputs format, the $\times 1$ and $\times 2$ variables of the model were renamed to "SCBA" (which represents the SCBA/s rates) and "Super" (which represents $\mathrm{sp} / c$ ratio), respectively, and the responses were defined as $G_{\mathrm{m}}$ and $R_{\mathrm{m}}$.

Table 4 uses the optimum experimental results of dosage for all the ranges of SCBA/s analyzed, with the mortar with $20 \%$ (SCM 13) as center point. The optimum mortars with replacement of 5\% (SCM 5) and 25\% (SCM 17) were not used because they were not equidistant from the central reference. To extend the analysis points, it was used the concept of distribution of the central composite rotational design (CCRD), with the coordinated points (SCBA, Super): $(0,1.41),(0,-1.41),(1.41,0)$ and $(-1.41,0)$. The $G_{\mathrm{m}}$ and $R_{\mathrm{m}}$ values for these points were assumed by extrapolation of the optimum values of the seven SCMs. This configuration has central, axial and rotational points, which are characteristic for the adjustment of the second-order models. The coefficients of the model were estimated with RSM library and are depicted in Table 5.

As given in Table 5, it is possible to present Eq. (4) and Eq. (5), which describe the second-order response surface models for $G_{\mathrm{m}}$ and $R_{\mathrm{m}}$, for the predictions of the coded values.

$$
\begin{aligned}
& \hat{G}_{\mathrm{m}}=4.23+1.75 \mathrm{SCBA}-1.89 \text { Super }-1.64 \mathrm{SCBA}^{2}-1.80 \text { Super }^{2}+4.38(\mathrm{SCBA} \times \text { Super }) \\
& \hat{R}_{\mathrm{m}}=0.95-0.04 \mathrm{SCBA}+0.06 \text { Super }+0.12 \mathrm{SCBA}^{2}+0.06 \mathrm{Super}^{2}-0.17(\mathrm{SCBA} \times \text { Super })
\end{aligned}
$$

All the coefficients generated by the models can provide reliable results with at least $99 \%$ of confidence, which is corroborated by the $p$ value $(\alpha)$ of the two models, 6.262e-06 for $G_{\mathrm{m}}$ and 0.001189 for $R_{\mathrm{m}}$. Figure 7 shows the perspective of the predicted values versus observed values for $G_{\mathrm{m}}$ and $R_{\mathrm{m}}$. The values of the coefficient of determination $R^{2}$ of 0.9998 for $G_{\mathrm{m}}$ and of 0995 for $R_{\mathrm{m}}$ show the existence of an optimum numerical correlation between the observed and predicted values in both models.

Table 4 Coded data for the model studies

\begin{tabular}{lllrl}
\hline Reference & SCBA $\left(x_{1}\right)$ & Super $\left(x_{2}\right)$ & $G_{\mathrm{m}}$ & $R_{\mathrm{m}}$ \\
\hline SCM 0 & -1 & -1.00 & 5.27 & 0.93 \\
SCM 9 & -0.5 & -0.78 & 5.11 & 0.94 \\
SCM 13 & 0 & -0.78 & 4.57 & 0.93 \\
SCM 20 & 0.5 & 0.11 & 4.68 & 0.95 \\
SCM 25 & 1 & 1.00 & 5.03 & 0.98 \\
Rotational & 0 & 1.41 & 3.43 & 1.14 \\
Rotational & 0 & -1.41 & -1.52 & 1.24 \\
Rotational & 1.41 & 0 & -2.04 & 1.15 \\
Rotational & -1.41 & 0 & 3.30 & 0.99 \\
\hline
\end{tabular}




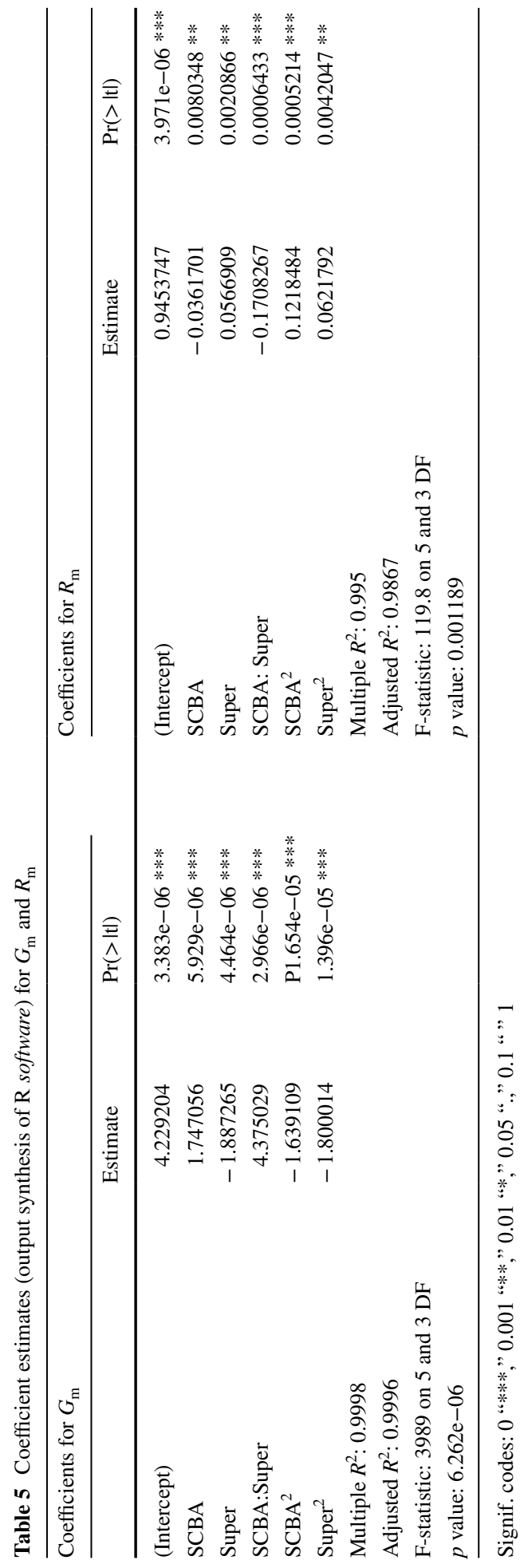



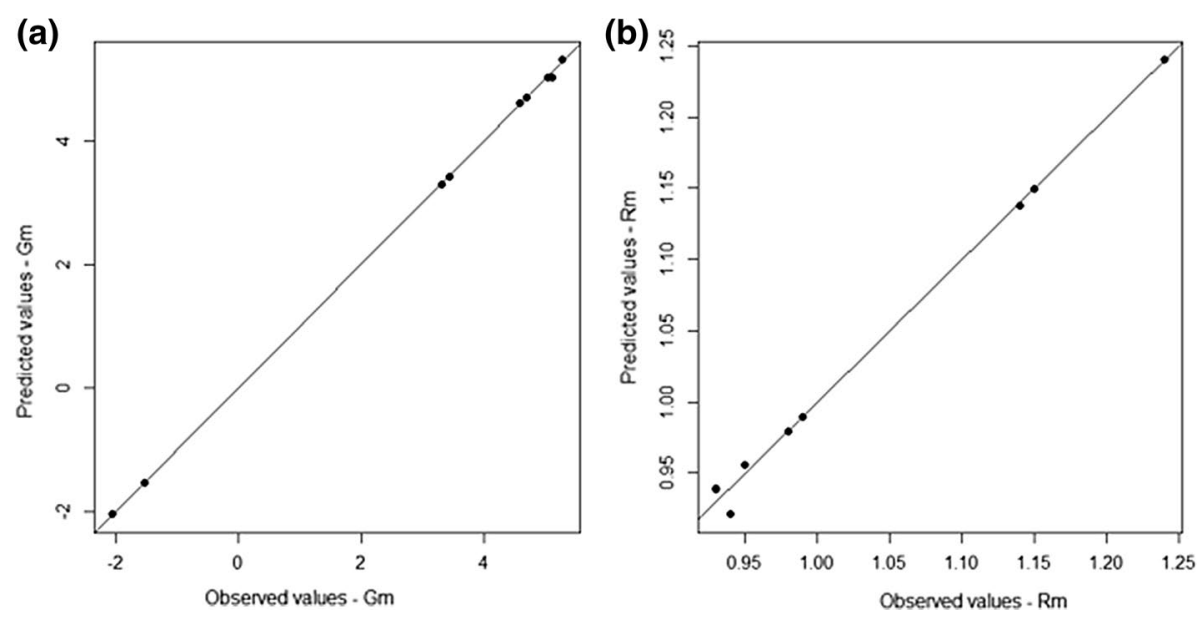

Fig. 7 Graphical comparison of predicted and experimental values of $G_{\mathrm{m}}$ and $R_{\mathrm{m}}$. (a) Graph of experimental values versus predicted values for $G_{\mathrm{m}}$; (b) graph of experimental values versus predicted values for $R_{\mathrm{m}}$

The response surfaces graphs and their respective contours were generated in view of the information that validates the models (Fig. 8).

In Fig. 8, by the predictions that can reproduce the expected yields in the $G_{\mathrm{m}}(5 \pm 0.5)$ and $R_{\mathrm{m}}(1 \pm 0.1)$ tests, it can be visualized that there are good amplitudes of combinations of $\mathrm{SCBA} / \mathrm{s}$ and $\mathrm{sp} / c$. Besides that, it is important to emphasize that it is possible to reproduce compositions of SCMs in all replacement ranges of SCBA/s, with increasing consumption of $\mathrm{sp} / c$ as the SCBA is added, something that had already been noticed in the experiments.

Through the generated contour graphs, it is possible to verify that there are broad central bands that would simultaneously represent satisfactory results of $G_{\mathrm{m}}$ and $R_{\mathrm{m}}$. Furthermore, it can be noticed that the optimum points of yields (maximum) are close to the center of the graphs, slightly shifted down.

The maximum performance of $G_{\mathrm{m}}$, by adjusting the response surface model in R software, corresponds to the point of coordinates $(0.27 ;-0.20)$. It represents effectively the $\mathrm{SCBA} / \mathrm{s}$ ratio of $25.4 \%$ and $\mathrm{sp} / \mathrm{c}$ ratio of 0.47 with the predicted value of 4.65 for $G_{\mathrm{m}}$. It is also located in the optimum band of $R_{\mathrm{m}}$ with a projection of 0.94 . It is highlighted that the experimental results of SCM 17, which has the SCBA/s ratio of $25 \%$ and sp/c of 0.45 , with $G_{\mathrm{m}}$ and $R_{\mathrm{m}}$ experimental values of 4.78 and 1 , respectively, and although it has not been part of the analysis of the CCRD, present proximity to the prediction values that obtained the maximum performance. Above all, it is important to highlight that it was verified that the optimum values obtained in the $G_{\mathrm{m}}$ and $R_{\mathrm{m}}$ tests predict that it is possible, by the mathematical model, to reproduce the values satisfactorily, with a reliability higher than $99 \%$.

\section{Conclusions}

In this paper, it was studied different compositions of SCM with the addition of SCBA by means of the relative flow area and relative flow time. The reference sample (SCM 0) had only sand as fine aggregate and required the same amount of superplasticizer as observed 

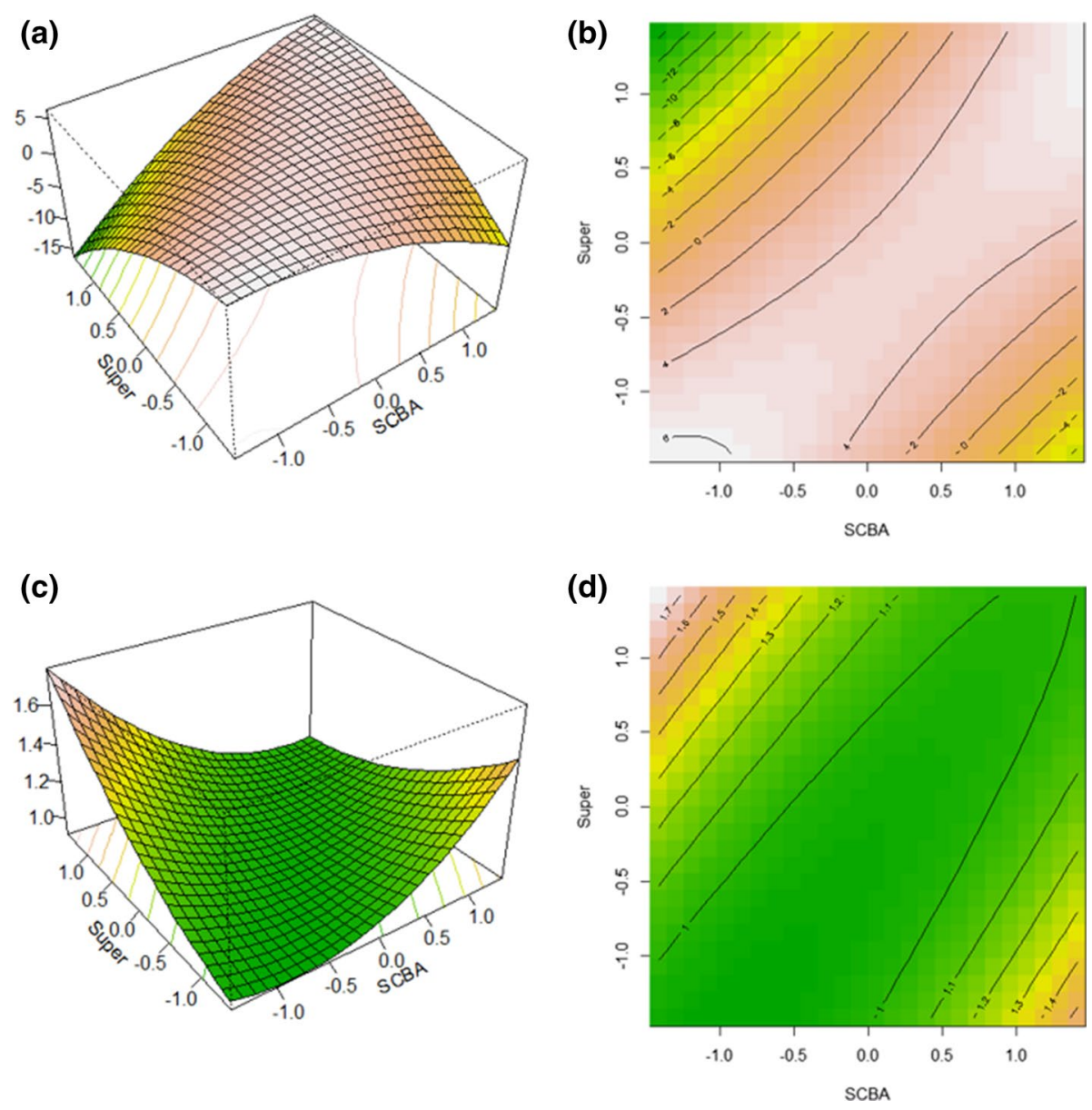

Fig. 8 Representation of the surface responses and respective contours of $G_{\mathrm{m}}$ and $R_{\mathrm{m}}$. a Response surface graph for $G_{\mathrm{m}} ; \mathbf{b}$ contour graph for $G_{\mathrm{m}}$; $\mathbf{c}$ response surface graph for $R_{\mathrm{m}} ; \mathbf{d}$ contour graph for $R_{\mathrm{m}}$

in the paste of Molin Filho et al. (2011) to maintain the expected rheological properties in the mortar. SCM 25, which represents the best composition for the replacement rate of $40 \%$ of sand by SCBA, although requested a $\mathrm{sp} / c=0.0058$ ratio, also presents interesting consumption values of materials for mortars with self-compacting properties.

It was demonstrated that it was possible to develop mortars with self-compacting properties with maximum $\mathrm{sp} / c$ consumption of $0.58 \%$ for the replacement rates between 5 and $40 \%$ of sand by SCBA. These percentages of replacement generated reduction in the cement and sand consumption per $\mathrm{m}^{3}$ in the mortars in relation to the trace of mortar that did not contain SCBA. This reduction was of $11 \%(56 \mathrm{~kg})$ for the cement and reached $46 \%$ (489 kg) in the case of the sand, for the replacement rate of 40\%. SCM 25 composition would allow the production of more than 13 million $\mathrm{m}^{3}$ of self-compacting concrete by using all the potential of SCBA generation of the annual harvest. This volume of SCC would be sufficient for the construction of more than 160 stadiums like the original project of Maracanã Olympic stadium. These values show an excellent alternative to the reuse of 
the residues from the burning of the sugarcane bagasse, as much for the recycling as for the possible development of a product with quality comparable to those of current use. In addition, this application enables a suitable technical destination for SCBCA and has the potential to promote the deceleration of the use of natural resources, such as cement, sand and water in self-supporting mortars. In this way, advances are presented in the development of new products that directly contribute to the advancement of socio-environmental values, both for generating plants and for use in civil construction in favor of the advance of buildings. Although the statistical and rheological studies in the fresh state have shown substitution possibilities expressively greater than the usual compositions, new studies in the hardened state are recommended for the final proof of the proposed ideas.

Acknowledgements This work was supported by Coordenação de Aperfeiçoamento de Pessoal de Nível Superior (CAPES) and the civil construction materials laboratory of DEC-UEM. The SCBA and additives were suported by Usaçúcar Group and BASF S/A in Brazil, respectively.

\section{References}

Associação Brasileira de Normas Técnicas - ABNT. (2009). NBR 7211. Agregados para concreto - Especificação (aggregates for concrete-specification). Rio de Janeiro, Brazil.

Associação Brasileira de Normas Técnicas - ABNT. (2009). NBR 15900-1. Água para amassamento do concreto - requisitos (mixing water for concrete part 1: requirements). Rio de Janeiro, Brazil.

Associação Brasileira de Normas Técnicas - ABNT. (2004). NBR 10004. Resíduos Sólidos - classificação (solid waste-classification). Rio de Janeiro, Brazil.

Associação Brasileira de Normas Técnicas - ABNT. (2014). NBR 5752. Materiais pozolânicos - Determinação do índice de desempenho com cimento Portland aos 28 dias (pozzolanic materials-determination of the performance index with Portland cement at 28 days). Rio de Janeiro, Brazil.

Associação Brasileira de Normas Técnicas - ABNT. (2016). NBR 7181. Solo - Análise granulométrica (soil-grain size analysis). Rio de Janeiro, Brazil.

Associação Brasileira de Normas Técnicas - ABNT. (2017). NBR 15823-1: Concreto auto-adensável. Parte 1: Classificação, controle e aceitação no estado fresco (self compacting concrete. part 1: Classification, control and acceptance in the fresh state). Rio de Janeiro, Brazil.

Bahurudeen, A., \& Santhanam, M. (2015). Influence of different processing methods on the pozzolanic performance of sugarcane bagasse ash. Cement \& Concrete Composites. https://doi.org/10.1016/j.cemco ncomp.2014.11.002.

Chatterjee, A., \& Das, D. (2013). Assessing flow response of self-compacting mortar by Taguchi method and ANOVA interaction. Materials Research. https://doi.org/10.1590/S1516-14392013005000083.

Companhia Nacional de Abastecimento - CONAB. (2017). Acompanhamento da safra brasileira: cana-deaçúcar. Segundo levantamento da safra 2017/2018, agosto. http://www.conab.gov.br/OlalaCMS/uploa ds/arquivos/17_08_24_08_59_54_boletim_cana_portugues_-_2o_lev_-_17-18.pdf. Accessed 20 Sept 2017.

Crespi, M., Martins, Q., Almeida, S., Barud, H., Kobelnik, M., \& Ribeiro, C. (2011). Characterization and thermal behavior of residues from industrial sugarcane processing. Journal of Thermal Analysis and Calorimetry. https://doi.org/10.1007/s10973-011-1397-9.

Edamatsu, Y., Nishida, N., Ouchi, M. A. (1999). Rational mix-design method for self compacting concrete considering interaction between coarse aggregate and mortar particles. In A. Skarendahl \& Ö. Petersson (Eds.), Proceedings of the first international RILEM symposium on self-compacting concrete; September 13-14, 1999; Stockholm, Sweden. Stockholm: A. RILEM Publications S.A.R.L. pp. 309-320.

European Federation which Unites National Associations and Companies - EFNARC. (2005). The Europe guidelines for self-compacting. concrete-specification, production and use. http://www.EFNARC.org/ pdf/SCCGuidelinesMay2005.pdf. Accessed 23 Sept 2017.

Faria, K. C. P., Gurgel, R. F., \& Holanda, J. N. F. (2012). Recycling of sugarcane bagasse ash waste in the production of clay bricks. Journal of Environmental Management. https://doi.org/10.1016/j.jenvm an.2012.01.032.

Federação das Indústrias do Estado de São Paulo/Centro das Indústrias do Estado de São Paulo - FIESP/ CIESP. (2012). Ampliação da oferta de energia através da biomassa. http://www.fiesp.com.br/indic 
es-pesquisas-e-publicacoes/ampliacao-da-oferta-de-energia-atraves-de-biomassa/. Accessed 13 July 2017.

Gomes, P. C. C. (2003) Optimization and characterization of high-strength self- compacting concrete. Thesis-Doctorate in Civil Engineering. Barcelona: School of D'Enginyeria of Construction of Camins, Universitat Politecnica of Catalunya, p 139.

Gomes, P. C. C., \& de Barros, A. R. (2009). Métodos de dosagem de concreto autoadensável (1st ed.). São Paulo: Pini.

Itaipu Binacional. (2017). Concretagem. https://www.itaipu.gov.br/energia/concretagem. Accessed 25 Oct 2017.

Lager, G. A., Jorgensen, J. D., \& Rotella, F. J. (1982). Crystal structure and thermal expansion of $\alpha$-quartz $\mathrm{SiO}_{2}$ at low temperatures. Journal of Applied Physics, doi, 10(1063/1), 330062.

Madandoust, R., Mohseni, E., Mousavi, S. Y., \& Namnevis, M. (2015). An experimental investigation on the durability of self-compacting mortar containing nano- $\mathrm{SiO}_{2}$, nano- $\mathrm{Fe}_{2} \mathrm{O}_{3}$ and nano-CuO. Construction and Building Materials. https://doi.org/10.1016/j.conbuildmat.2015.03.100.

Modani, P. O., \& Vyawahare, M. R. (2013). Utilization of bagasse ash as a partial replacement of fine aggregate in concrete. Procedia Engineering. https://doi.org/10.1016/j.proeng.2013.01.007.

Mohseni, E., Miyandehi, B. M., Yang, J., \& Yazdi, M. A. (2015). Single and combined effects of nano-SiO ${ }_{2}$, nano- $\mathrm{Al}_{2} \mathrm{O}_{3}$ and nano- $\mathrm{TiO}_{2}$ on the mechanical, rheological and durability properties of self-compacting mortar containing fly ash. Construction and Building Materials. https://doi.org/10.1016/j.conbu ildmat.2015.03.006.

Moisés, M. P., Silva, C. T. P. da, Meneguin, J. G., Girotto, E. M., \& Radovanovic, E. (2013). Synthesis of zeolite NaA from sugarcane bagasse ash. Materials Letters. https://doi.org/10.1016/j.matle t.2013.06.086.

Molin Filho, R. G. D., Vanderlei, R. D., Kim, L. S., Watanabe, O. T. Q., \& Nagano, M. F. (2011). Análise reológica da pasta de cimento para concreto autoadensável (Rheological analysis of cement paste for self-compacting concrete) [CD- ROM]. In SOARES, D. A. F (Eds.), Proceedings of the IX Encontro Tecnológico da Engenharia Civil e Arquitetura, October 01-03, 2013. State University of Maringá, Maringá, Brazil.

Moretti, J. P., Sales, A., Almeida, F. C. R., Rezende, M. A. M., \& Gromboni, P. P. (2016). Joint use of construction waste (CW) and sugarcane bagasse ash sand (SBAS). Construction and Building Materials. https://doi.org/10.1016/j.conbuildmat.2016.03.062.

Nepomuceno, M., Oliveira, L., \& Lopes, S. M. R. (2012). Methodology for mix design of the mortar phase of self-compacting concrete using different mineral additions in binary blends of powders. Construction and Building Materials. https://doi.org/10.1016/j.conbuildmat.2011.06.027.

Nogueira, N. O., Tomaz, M. A., Andrade, F. V., Reis, E. F. D., \& Brinatem, S. V. B. (2012). Influência da aplicação de dois resíduos industriais nas propriedades químicas de dois solos cultivados com café arábica (Influence of the application of two industrial residues on the chemical properties of two soils cultivated with Arabica coffee). Ciências Agronômicas. https://doi.org/10.1590/S1806-6690201200 0100002 .

Nunes, S. C. B. (2001). Betão Auto-Compactível: Tecnologia e Propriedades (self-compacting concrete: technology and properties). Dissertation-Master's degree in Structural Engineering, Porto: Engineering Department, University of Porto, p 198.

Okamura, H., \& Ouchi, M. (1999). Self-compacting concrete. Development, present use and future. In A. Skarendahl \& Ö. Petersson (Eds.), Proceedings of the first international RILEM symposium on selfcompacting concrete, September 13-14, 1999. Stockholm, Sweden. Stockholm: RILEM Publications S.A.R.L. 3-14.

Okamura, H., \& Ouchi, M. (2003). Self-compacting concrete. Jornal of Advance Concrete Technology, 1(1), $5-15$.

R Development Core Team. (2016). The R Project for Statistical Computing. R Foundation for Statistical Computing, Vienna, Austria. https://www.r-project.org/. Accessed 5 Aug 2016.

Rao, S., Silva, P., \& De Brito, J. (2015). Experimental study of the mechanical properties and durability of self-compacting mortars with nano materials $\left(\mathrm{SiO}_{2}\right.$ and $\left.\mathrm{TiO}_{2}\right)$. Construction and Building Materials. https://doi.org/10.1016/j.conbuildmat.2015.08.049.

Safi, B., Ghernouti, Y., Rabehi, B., \& Aboutaleb, D. (2013). Effect of the heat curing on strength development of self-compacting mortars containing calcined silt of dams and ground brick waste. Materials Research. https://doi.org/10.1590/S1516-14392013005000094.

Sales, A., \& Lima, S. A. (2010). Use of Brazilian sugarcane bagasse ash in concrete as sand replacement. Waste Management. https://doi.org/10.1016/j.wasman.2010.01.026.

Santos, A. (2011). Maracanã encolhe, mas ganha inovações e sustentabilidade. http://www.cimentoitambe. com.br/maracana-encolhe-mas-ganha-inovacoes-e-sustentabilidade. Accessed 24 Oct 2017. 
Silva, P. R. da, \& Brito, J. de (2015). Fresh-state properties of self-compacting mortar and concrete with combined use of limestone filler and fly ash. Materials Research. https://doi.org/10.1590/15161439.028715 .

Takada, K., Walraven, J.C. Influence of mixing efficiency on the properties of flowable cement pastes. In Ozaka K. Ouchi M (Eds.), Proceedings of the second international RILEM symposium on self-compacting concrete; 23-25 October 2001; Tokyo, Japan. Tokyo. pp. 545-554.

Vanderlei, R. D., Peinado, H. S., Nagano, M. F., \& Molin Filho, R. G. D. (2014). Uso da cinza do bagaço de cana-de-açúcar como agregado em concretos e argamassas. REEC - Revista eletrônica de Engenharia Cívil, https://doi.org/10.5216/reec.v8i1.26534.

Zhang, L. (2013). Production of bricks from waste materials-A review. Construction and Building Materials. https://doi.org/10.1016/j.conbuildmat.2013.05.043. 